\title{
Occurrence of sperm whale (Physeter macrocephalus) in the Russian Arctic
}

\author{
Igor Popov' (1) \& Götz Eichhorn' 2,3 (1) \\ 'Department of Applied Ecology, Faculty of Biology, Saint-Petersburg State University, Saint-Petersburg, Russia; \\ ${ }^{2}$ Vogeltrekstation-Dutch Centre for Avian Migration and Demography, Netherlands Institute of Ecology, Wageningen, The Netherlands; \\ ${ }^{3}$ Department of Animal Ecology, Netherlands Institute of Ecology, Wageningen, The Netherlands
}

\begin{abstract}
We report two sperm whale (Physeter macrocephalus) strandings observed in the south-east corner of the Barents Sea (i.e., Pechora Sea) in 2018, unusually far from the species' hitherto known distribution. While compiling a comprehensive overview of the occurrence of sperm whale sightings and strandings in the Russian Arctic, we learnt about one further stranding in the Pechora Sea, observed in 2017. All other records were from sites considerably closer to the species' usual distribution. Reports from the eastern Russian Arctic suggest that sperm whales rarely, if ever, entered the Arctic from the Pacific Ocean. Although observed occurrences in the Russian Barents Sea have been few and sporadic, the occurrence of sperm whales in its south-eastern section appears to be a recent phenomenon, which is possibly related to declining sea-ice cover.
\end{abstract}

\section{Keywords}

Marine mammals; climate change; range expansion; stranding; distribution; Barents Sea

\section{Correspondence \\ Igor Popov, Department of Applied Ecology, Faculty of Biology, Saint-Petersburg State University, Universitetskaya n. 7/9, 199034 Saint-Petersburg, Russia. E-mail: igorioshapopov@mail.ru}

\section{Introduction}

Sperm whales (Physeter macrocephalus) have a broad global distribution and are found from tropical to temperate zones in every ocean (Jefferson et al. 2008). They usually forage in deep waters, where they routinely dive to depths of 400-900 m, with a maximum recorded depth of $2250 \mathrm{~m}$ (Ponganis 2015). Although sperm whales occasionally move into shallow waters, such behaviour can result in stranding incidents (Ijsseldijk et al. 2018). Adult male sperm whales often undertake seasonal migrations to northern waters, where they approach the ice edge (Halpin et al. 2009; Øien 2009; Eriksen 2014; Storrie et al. 2018). Because of their shallowness and ice coverage, most parts of the Arctic shelf seas are not suitable habitat for this species. Russian Arctic seas seem particularly unsuitable for sperm whales given their shallow depths over wide continental shelves; deeper areas are usually covered by ice year-round. Herein, we report our recent observation of two stranded sperm whales on the Russian Barents Sea coast, far from their usual distribution. We also report the results of an extensive search through public archives for further information on the occurrence of sperm whales in the Russian Arctic, including both live sightings at sea and observations of stranded (dead) whales.

\section{Two dead sperm whales on a Pechora sea beach}

As members of a larger expedition of animal ecologists, we visited the abandoned settlement of Tobseda, located at the mouth of Kolokolkova Bay $\left(68.6^{\circ} \mathrm{N} 52.3^{\circ} \mathrm{E}\right)$ in the south-eastern Barents Sea (i.e., Pechora Sea), in 2018. Twelve $\mathrm{km}$ north-east of Tobseda, one sperm whale had been found lying on the seashore by a local hunter (Yakov A. Moskvin) at the end of May, at a time when ice covered the coastal zone. He relayed this information to our fellow expedition members, who visited the site on 18 June. They found two sperm whales at a distance of $180 \mathrm{~m}$ from each other; the second had been previously hidden by ice. We inspected the carcasses ourselves on 30 July 2018. Both whales were adult males, $15.2 \mathrm{~m}$ and $16.0 \mathrm{~m}$ in total body length, respectively. On the exposed parts (left lateral sides), we could not detect any wounds. The whales appeared to be in similar states of advanced decomposition (Fig. 1). The hunter who first found the carcass on this beach, when it was still covered by ice in May 2018, did not observe the carcasses when he visited the same site in August the year before. It therefore seems likely that the strandings occurred in the period between (end of) August and November 2017, before the freeze-up of the 
sea (Batalkina et al. 2007). This record is nearly 1000 $\mathrm{km}$ from the nearest known sightings of sperm whales at sea (Fig. 2).
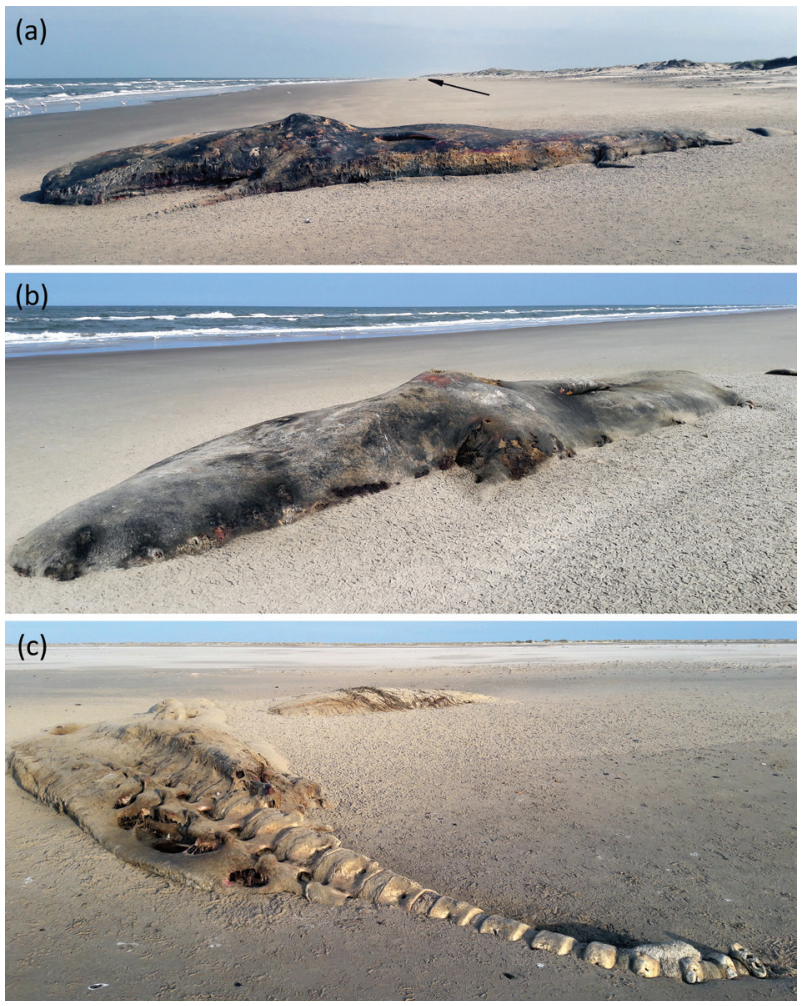

Fig. 1 Two sperm whales found by us on the Barents Sea coast near Tobseda. An arrow in (a) indicates the second specimen (b), about $180 \mathrm{~m}$ away. Photographs (a) and (b) were taken on 30 July 2018. (c) The same individual featured in (a) one year later: 22 July 2019 (the other individual was buried in sand).

\section{Other sperm whale observations in the Russian Arctic}

To investigate other records of sperm whales in the Russian Arctic (i.e., Russian waters north of the Arctic Circle), we searched the following sources in August 2018-May 2019: the library and archive of the regional museum in Naryan-Mar (http://www.naomuseum.ru), where we also consulted with its researchers about possibly unpublished local observations of sperm whales; the library of the Russian Academy of Science, which hosts one of the largest and oldest literature archives for the country; the Russian citation index (https://elibrary. $\mathrm{ru}$ ); reports of the Russian Geographical Society (http:// www.rgo.ru); reports of the Russian Arctic National Park (http://www.rus-arc.ru); online resources and databases of the Arctic and Antarctic Research Institute (http://oopt. aari.ru/; http://www.aari.ru); the Red List of threatened species and related topics for the whole of Russia (http:// redbookrf.ru, http://www.sevin.ru/redbooksevin); Russian media accounts published on the world wide web; the online archive hosted by the Global Biodiversity Information Facility Secretariat (https://www.gbif.org); and the Ocean Biogeographic Information System Spatial Ecological Analysis of Megavertebrate Populations archive (http://seamap.env.duke.edu).

These sources yielded few additional records for the Russian section of the Barents Sea. Notably, in 2017, fishermen found a stranded sperm whale at the mouth of the Pechora River, approximately $160 \mathrm{~km}$ east of Tobseda; a photograph in a local newspaper documents a large male that likely stranded during the second half of 2016 given its state of decay. Prior to 2017, the only other strandings documented occurred on the Kanin Peninsula in 1932 and 1982. Most recently, a stranded sperm whale was

Table 1 Summary of sperm whale occurrences in the Russian section of the Barents Sea. See Fig. 2 for a map of occurrences.

\begin{tabular}{|c|c|c|c|c|}
\hline Occurrence & Year & Site, approximate co-ordinates & Circumstances & Source \\
\hline 1 & 1932 & $\begin{array}{l}\text { West coast of Kanin Peninsula } \\
68.4^{\circ} \mathrm{N}, 43.9^{\circ} \mathrm{E}\end{array}$ & Dead on beach, 1 individual & Ognetov 1983 \\
\hline 2 & 1982 & $\begin{array}{l}\text { West coast of Kanin Peninsula } \\
67.5^{\circ} \mathrm{N}, 43.7^{\circ} \mathrm{E}\end{array}$ & Dead on beach, 1 individual & Ognetov 1983 \\
\hline 3 & 2007 & $\begin{array}{l}\text { Central Barents Sea } \\
74.7^{\circ} \mathrm{N}, 29.1^{\circ} \mathrm{E}\end{array}$ & $\begin{array}{l}\text { Live sighting, } \\
1 \text { individual }\end{array}$ & Anonymous 2007 \\
\hline 4 & 2013 & $\begin{array}{l}\text { Central Barents Sea } \\
74.2^{\circ} \mathrm{N}, 35.1^{\circ} \mathrm{E}\end{array}$ & $\begin{array}{l}\text { Live sighting, } \\
1 \text { individual }\end{array}$ & Klepikovskij et al. 2017 \\
\hline 5 & 2017 & $\begin{array}{l}\text { South-eastern Barents Sea } \\
68.9^{\circ} \mathrm{N}, 57.4^{\circ} \mathrm{E}\end{array}$ & Dead on beach, 1 individual & $\begin{array}{l}\text { http://dvinatoday.ru/news/gigantskuyu-tushu- } \\
\text { kashalota-vybrosilo-na-bereg-morya-v-nao }\end{array}$ \\
\hline 6 & 2018 & $\begin{array}{l}\text { South-eastern Barents Sea } \\
68.7^{\circ} \mathrm{N}, 52.6^{\circ} \mathrm{E}\end{array}$ & Dead on beach, 2 individuals & Our data \\
\hline
\end{tabular}




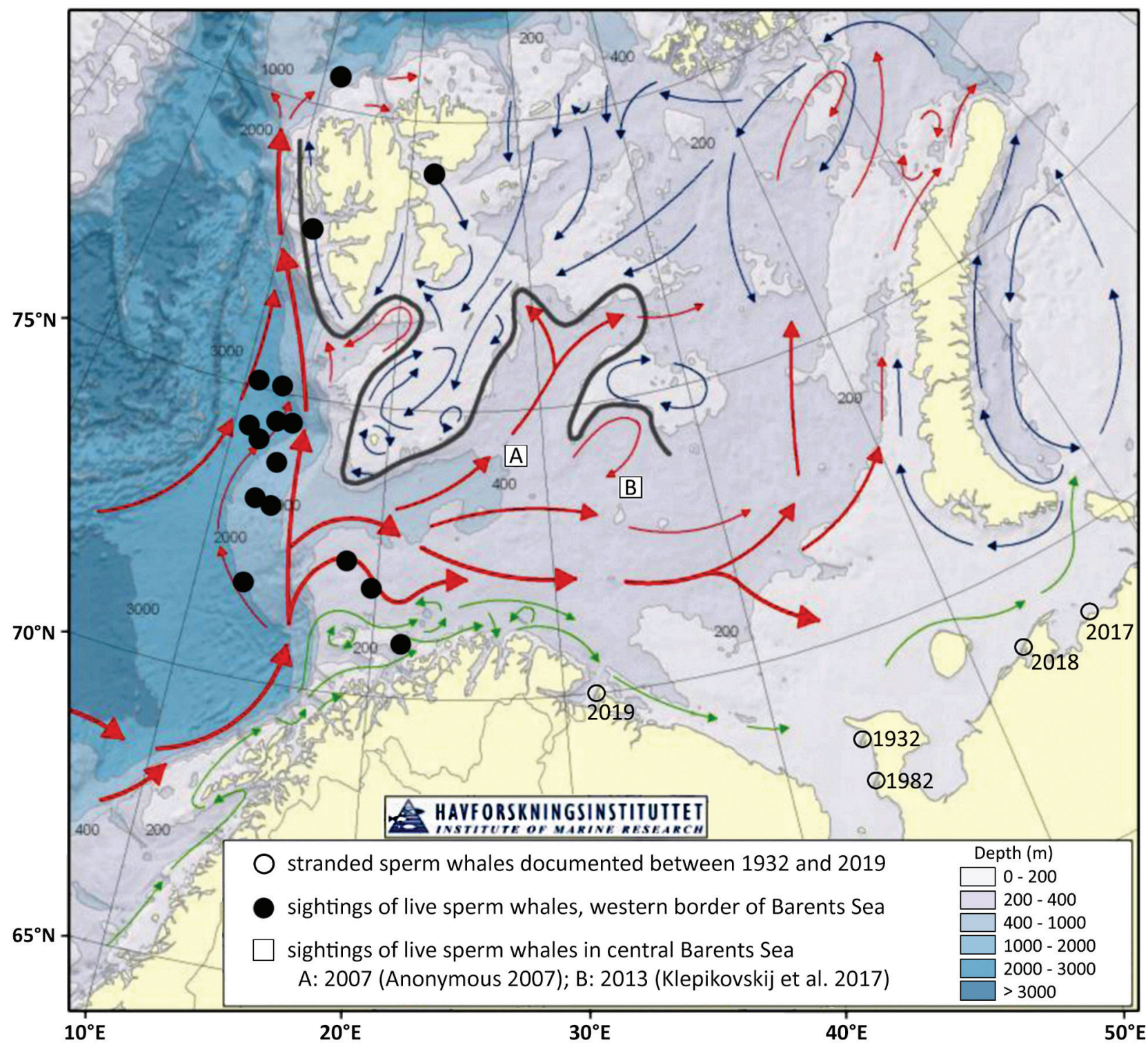

Fig. 2 Locations of sperm whales stranded along the Russian Barents Sea coast (see Table 1 for occurrence numbers) and nearest sightings of live individuals at sea (data from www.bif.org and http://seampa.env.duke.edu). See Table 1 and main text for more details. The background map is reprinted with kind permission of Arneberg et al. (2009).

found in the Aynovy Islands (Murmanskaya Oblast), near the border with Norway in 2019, relatively close to the species' usual occurrence. Sperm whales have been regularly sighted in the western Barents Sea between Norway and Svalbard. Since 2007, two sightings have been reported from the central Barents Sea (Table 1, Fig. 2).

\section{Discussion}

The sperm whales found on the Russian Barents Sea coast were all found dead. It remains uncertain if they succumbed by stranding on the beach or died at sea further away before being washed ashore. The Tobseda observation, however, involved two carcasses in similar states of decay found close to each other on the same beach. This makes it more likely that these two whales travelled together and probably stranded together on this beach, or at least did not die far from it. Sperm whale strandings, including mass strandings of a group of individuals, are not an uncommon phenomenon (Thalmann et al. 2008). A variety of factors have been suggested to be related to this phenomenon, such as lunar cycles (Wright 2005), solar storms resulting in alternation of 
the Earth's magnetic field (Vanselow et al. 2018), largescale climate events (Evans et al. 2005), contaminants or heavy metal pollution (Squadrone et al. 2015) and disease (Hansen et al. 2016). Seismic activity might also be considered a potential factor (Mazzariol et al. 2011). In many cases, however, multi-factorial causes may apply (Mazzariol et al. 201 1; Hansen et al. 2016; Ijsseldijk et al. 2018; Mazzariol et al. 2018). Although we do not know the cause of strandings in the shallow south-eastern corner of the Barents Sea, this might be reminiscent of the so-called "North Sea trap." It is thought that male sperm whales that have spent the summer in the North Atlantic and Norwegian waters on their southward migration erroneously round the British Islands from the east and end up in increasingly narrower and shallower waters of the North Sea until they strand (Hansen et al. 2016; Ijsseldijk et al. 2018).

In the eastern parts of the Russian Arctic, sightings made during the mid-20th century indicate that sperm whales sporadically occurred at the southern limit of the Chukchi Sea, close to the Bering Strait (Vinogradov 1949; Arseniev 1961). Later observations from the Chukchi Peninsula revealed no evidence of sperm whales entering the Arctic Ocean (Bogoslovskaja 2003). Historical and current data suggest that sperm whales rarely, if ever, enter the Arctic from the Pacific Ocean, despite their relatively high abundance in the North Pacific (Mizroch $\delta$ Rice 2013; Ivashchenko et al. 2014). This may change in the foreseeable future. Although the global population is only slowly recovering (and not in all regions equally) from a low level at the cease of large-scale sperm whaling in 1988 (Whitehead 2002), the number of sperm whale sightings has been increasing in the northern Bering Sea (Bogoslovskaja 2003; Litovka \& Kochnev 2008; Fomin et al. 2010). Several species of marine mammals have expanded their ranges westward from the Chukchi Sea. The northern sea lion (Eumetopias jubatus) occurred only in small numbers at the Bering Strait in the 1980s but has now been sighted at several locations in the East Siberian Sea up to the Kolyma River (Boeskorov et al. 2011). Bowhead whales (Balaena mysticetus) have extended their range towards the western part of the East Siberian Sea, and grey whales (Eschrichtius robustus) have spread even further westwards up to the eastern Laptev Sea (Boeskorov \& Davydov 2015).

Such range expansions may have been facilitated by increasing accessibility to new habitat and changing prey distribution associated with global warming. The Arctic Ocean has already experienced drastic reductions in sea-ice cover (Alexeev et al. 2017; Wang et al. 2019). Recent warming has been linked to northward range expansions of several cetacean species including sperm whales around Svalbard (Storrie et al. 2018). Changes in climate and prey accessibility may pave the way for sperm whales to explore formerly inaccessible areas, potentially also in the Russian Arctic. While their main prey consists of different cephalopod species, their diet range is broad and includes fish in some regions (Rice 1989). Although they hunt mainly in deep waters, foraging opportunities can draw them into very shallow waters, like the coast of Long Island, New York, where small groups of sperm whales have been observed regularly near shore, at depths of approximately $50 \mathrm{~m}$ (Scott \& Sadove 1997). Nonetheless, shallow water is probably limiting the range expansion of sperm whales in the Russian Arctic.

\section{Acknowledgements}

The authors thank the members of the 2018 field expedition to Tobseda for their good company, Yakov Moskvin for alerting us to the stranded whales and Andrew Ostrovsky, Alexey Diukov, Manfred Enstipp, Kit Kovacs and Lonneke Ijsseldijk for their helpful comments on earlier versions of the manuscript.

\section{Funding}

IP thanks the Saint-Petersburg State University for research grant no. 28612627. GE received funding from the Netherlands Polar Programme (ALWP.2016.030) of the Netherlands Organization for Scientific Research.

\section{Disclosure statement}

The authors report no conflict of interest.

\section{References}

Alexeev V.A., Walsh J.E., Ivanov V.V., Semenov V.A. \& Smirnov A. 2017. Warming in the Nordic seas, North Atlantic storms and thinning Arctic sea ice. Environmental Research Letters 12, 084011, doi: 10.1088/1748-9326/ aa7ald.

Anonymous 2007. Survey report from the joint Norwegian/ Russian ecosystem. Survey in the Barents Sea August-October 2007. Vol. 1. IMR/PINRO Joint Report Series 4/2007. Bergen: Institute of Marine Research/Murmansk: Polar Research Institute of Marine Fisheries and Oceanography.

Arneberg P., Korneev O., Titov O., Stiansen J.E. (eds.), Filin A., Hansen J.R., Høines A. \& Marasaev S. (co-eds.) 2009. Joint Norwegian-Russian environmental status 2008. Report on the Barents Sea ecosystem. Part I. Short version. IMR/PINRO Joint Report Series 2009-2. Bergen: Institute of Marine Research/Murmansk: Polar Research Institute of Marine Fisheries and Oceanography. 
Arsen'ev V.A. 1961. Rasprostranenie kitov v Beringovom more i vozmožnosti razvitija kitobojnogo promysla. (Distribution of whales in the Bering Sea and possibilities for development of whaling.) Trudy soveshaniy ikhtyologicheskoy komissii Academii nauk SSSR (Proceedings of meetings of the Ichthyology Commission of the Academy of Sciences of the USSR.) 12, 112-124.

Batalkina S.A., Belinskih A.L., Voroncov A.A., Mihajlov N.N., Nefedova G.I., Olejnikov S.A., Pereskokov A.I., Ul'janich I.G. \& Hačaturov O.H. 2007. Klimat morej Rossii i kljuchevih rajonov Mirovogo okeana. (Climate of the seas of Russia and key regions of the World ocean.) Obninsk: All-Russian Research Institute of Hydrometeorological Information World Data Center.

Boeskorov G.G. \& Davydov S.P. 2015. Zahody usatyh kitov v zapadnuju čast 'Vostočno-Sibirskogo morja i na Vostočnuju okrainu morja Laptevih. (Penetrations of baleen whales to the western part of the East Siberian and the eastern margin of the Laptev Sea.) Vestnik SVNT DVO RAN 2, 69-74. (With English summary.)

Boeskorov G.G., Davydov S.P., Kočnev A.A. \& Lang E.M. 2011 . Proniknovenie sivuča Eumetopias jubatus v akvatorii Čukotskogo i vostočno-sibirskogo morej. (Penetration of the Steller's sea lion Eumetopias jubatus into waters of the Chukchi and East Siberian seas.) Zoologichesky Zhurnal 90, 123-128. (With English summary.)

Bogoslovskaja L.S. 2003. Kity Čukotki. Posobie dlja morskih ohotnikov. (Whales of Chukotka. Manual for sea hunters.) Moscow: Institut Naslediia.

Eriksen E. (ed.) 2014. Survey report from the joint Norwegian/ Russian ecosystem survey in the Barents Sea and adjacent waters, August-October 2014. IMR/PINRO Joint Report Series 1/2015. Bergen: Institute of Marine Research/Murmansk: Polar Research Institute of Marine Fisheries and Oceanography.

Evans K., Thresher R., Warneke R.M., Bradshaw C.J.A., Pook M., Thiele D. \& Hindell M.A. 2005. Periodic variability in cetacean strandings: links to large-scale climate events. Biology Letters 1, 147-150, doi: 10.1098/rsbl.2005.0313.

Fomin S.V., Fomin V.V. \& Mamaev E.G. 2010. Strandings of sperm whales (Physeter macrocephalus) on Commander Islands. In A.N. Boltunov (compiler): Marine mammals of the Holarctic. Collection of Scientific Papers after the Sixth International Conference. Pp. 593-596. Kaliningrad: Kapros.

Halpin P.N., Read A.J., Fujioka E., Best B.D., Donnelly B., Hazen L.J., Kot C., Urian K., La Brecque E., Dimatteo A., Cleary J., Caroline Good C., Crowder L.B. \& Hyrenbach K.D. 2009. OBIS-SEAMAP: the world data center for marine mammal, sea bird, and sea turtle distributions. Oceanography 22, 104-115, doi: 10.5670/oceanog.2009.42.

Hansen M.S., Alstrup A.K.O., Hansen J.H., Al-Sabi M.N.S., Nonnemann B., Jensen L.F., Hedayat A. \& Jensen T.H. 2016. Stranding of two sperm whales (Physeter macrocephalus) the "North Sea Trap" at Henne Strand, Denmark. Aquatic Mammals 42, 35-41, doi: 10.1578/AM.42.1.2016.35.

Ijsseldijk L.L., van Neer A., Deaville R., Begeman L., van de Bildt M., van den Brand J.M. A., Brownlow A., Czeck R., Dabin W., ten Doeschate M., Herder V., Herr H., Ijzer J., Jauniaux T., Jensen L.F., Jepson P.D., Jo W.K., Lakemeyer
J., Lehnert K., Leopold M.F., Osterhaus A., Perkins M.W., Piatkowski U., Prenger-Berninghoff E., Pund R., Wohlsein P., Gröne A. \& Siebert U. 2018. Beached bachelors: an extensive study on the largest recorded sperm whale Physeter macrocephalus mortality event in the North Sea. PLoS One 13, e0201221, doi: 10.1371/journal. pone.0201221.

Ivashchenko Y.V., Brownell R.L. Jr. \& Clapham P.J. 2014. Distribution of Soviet catches of sperm whales Physeter macrocephalus in the North Pacific. Endangered Species Research 25, 249-263, doi: 10.3354/esr00641.

Jefferson T.A., Webber M.A. \& Pitman R.L. 2008. Marine mammals of the world. A comprehensive guide to their identification. London: Academic Press.

Klepikovskij R.N., Lukin N.N. \& Mišin T.V. 2017. Sudovye issledovanija morskih mlekopitajuščih, provodimye PINRO v otkrytoj časti Barenceva morja. (Marine mammal ships research by PINRO carried out in the Barents Sea open part.) Trudy VNIRO 168, 125-133. (With English summary.)

Litovka D.I. \& Kočnev A.A. 2008. Kašalot Physeter catodon (macrocephalus) Linnaeus, 1758. (Sperm whale Physeter catodon [macrocephalus] Linnaeus, 1758.) In I.A. Čerešnev (ed.): Red data book of the Chukchi Autonomous District. V. 1 . Animals. Pp.184-185. Magadan: Dikiy Sever.

Mazzariol S., Centelleghe C., Cozzi B., Povinelli M., Marcer F., Ferri N., Di Francesco G., Badagliacca P., Profeta F., Olivieri V., Guccione S., Cocumelli C., Terracciano G., Troiano P., Beverelli M., Garibaldi F., Podesta M., Marsili L., Fossi M.C., Mattiucci S., Cipriani P., De Nurra D., Zaccaroni A., Rubini S., Berto D., de Quiros Y.B., Fernandez A., Morell M., Giorda F., Pautasso A., Modesto P., Casalone C. \& Di Guardo G. 2018. Multidisciplinary studies on a sick-leader syndromeassociated mass stranding of sperm whales (Physeter macrocephalus) along the Adriatic coast of Italy. Scientific Reports 8, article no. 11577, doi: 10.1038/s41598-018-29966-7.

Mazzariol S., Di Guardo G., Petrella A., Marsili L., Fossi C.M., Leonzio C., Zizzo N., Vizzini S., Gaspari S., Pavan G., Podesta M., Garibaldi F., Ferrante M., Copat C., Traversa D., Marcer F., Airoldi S., Frantzis A., De Beraldo Quiros Y., Cozzi B. \& Fernandez A. 2011 . Sometimes sperm whales (Physeter macrocephalus) cannot find their way back to the high seas: a multidisciplinary study on a mass stranding. PLoS One 6, e19417, doi: 10.1371/journal.pone.0019417.

Mizroch S.A. \& Rice D.W. 2013. Ocean nomads: distribution and movements of sperm whales in the North Pacific shown by whaling data and discovery marks. Marine Mammal Science 29, E136-E165, doi: 10.1111/j.1748-7692.2012.00601.x.

Ognetov G.N. 1983. Zakhody krupnikh kitov v Beloye more. (Occurrences of big whales in the White Sea.) Priroda 5, 100.

Øien N. 2009. Distribution and abundance of large whales in Norwegian and adjacent waters based on ship surveys 1995-2001. NAMMCO Scientific Publications 7, 31-47, doi: 10.7557/3.2704.

Ponganis P.J. 2015. Diving physiology of marine mammals and seabirds. Cambridge: Cambridge University Press. 
Rice D.W. 1989. Sperm whale Physeter macrocephalus Linneaus, 1758. In S.H. Ridgway \& R. Harrison (eds.): Handbook of marine mammals. Pp. 177-233. San Diego, CA: Academic Press.

Scott T.M. \& Sadove S.S. 1997. Sperm whale, Physeter macrocephalus, sightings in the shallow shelf waters off Long Island, New York. Marine Mammal Science 13, 317-321.

Squadrone S., Chiaravalle E., Gavinelli S., Monaco G., Rizzi M. \& Abete M.C. 2015. Analysis of mercury and methylmercury concentrations, and selenium: mercury molar ratios for a toxicological assessment of sperm whales (Physeter macrocephalus) in the most recent stranding event along the Adriatic coast (southern Italy, Mediterranean Sea). Chemosphere 138, 633-641, doi: 10.1016/j.chemosphere.2015.07.047.

Storrie L., Lydersen C., Andersen M., Wynn R.B. \& Kovacs K.M. 2018. Determining the species assemblage and habitat use of cetaceans in the Svalbard Archipelago, based on observations from 2002 to 2014. Polar Research 37, doi: $10.1080 / 17518369.2018 .1463065$.

Thalmann S., Gales R., Greenwood M. \& Gedamke J. 2008. A new technique for refloating and release of stranded sperm whales (Physeter macrocephalus). Marine Mammal Science 24, 949-955, doi: 10.1111/j.1748-7692.2008.00223.x.

Vanselow K.H., Jacobsen S., Hall C. \& Garthe S. 2018. Solar storms may trigger sperm whale strandings: explanation approaches for multiple strandings in the North Sea in 2016. International Journal of Astrobiology 17, 336-344, doi: 10.1017/S147355041700026X.

Vinogradov M.P. 1949. Morskije mlekopitajuščie Arktiki. (Marine mammals of the Arctic.) Leningrad: Arktichesky Institut.

Wang Y., Bi H., Huang H., Liu Y., Liu Y., Liang X., Fu M. \& Zhang Z. 2019. Satellite-observed trends in the Arctic sea ice concentration for the period 1979-2016. Journal of Oceanology and Limnology 37, 18-37, doi: 10.1007/ s00343-019-7284-0.

Whitehead H. 2002. Estimates of the current global population size and historical trajectory for sperm whales. Marine Ecology Progress Series 242, 295-304, doi: 10.3354/ meps242295.

Wright A.J. 2005. Lunar cycles and sperm whales (Physeter macrocephalus) strandings on the North Atlantic coastlines of the British Isles and Eastern Canada. Marine Mammal Science 21, 145-149, doi: 10.1111/j.1748-7692.2005.tb01214.x. 